\title{
MEZŐGAZDASÁGI TÁRSAS VÁLLALKOZÁSOK VIZSGÁLATA A KSH CÉG-KÓD-TÁR ADATBÁZISA ALAPJÁN
}

\author{
Hampel György \\ foiskolai docens, Szegedi Tudományegyetem, Mérnöki Kar
}

\begin{abstract}
SUMMARY
The enterprises which are involved in agriculture as their main activity represent about 1.7 percent of the Hungarian enterprises. Most of the food industry enterprises can be found in the Southern Great Plain Region, the Northern Great Plain and in Central Hungary (including the capital city). The most popular form of operation is the limited liability company (62\%) and the limited partnership (25\%). Nearly $90 \%$ can be considered as micro or small-sized companies, 55 percent has an annual income under 20 million HUF $(\sim 70,000 €), 83$ percent of the companies operate with less than 10 employees. Most of the firms are involved in growing of cereals (except rice), leguminous crops and oil seeds; support activities for crop production; raising of poultry; growing of vegetables and melons, roots and tubers; raising of swinę/pigs; growing of pome fruits and stone fruits; raising of dairy cattle and support activities for animal production. By calculating association coefficients, moderate connection was found between the place of headquarter and the form of operation, the main activity. There was a little bit weaker connection detectable between the place of headquarter and the number of employees or the annual income.
\end{abstract}

Kulcsszavak: mezōgazdasági társas vállalkozások, asszociációs vizsgálat

\section{BEVEZETÉS}

A magyar mezőgazdaság a 90-es években mély válságba került. Ennek oka részben az új kihívásokra való nem megfelelő reagálás, másrészt a gyökeres és gyors átalakulások, amelyek az ágazat teljesítményében és strukturális zavaraiban öltöttek testet (Kapronczai, 2007). A mezögazdasági termelés a 90-es évek elejéhez képest csökkent és még ma is csak megközelíti, ill. csak néhány esetben haladja meg az akkori szintet (KSH, 2011a) (KSH, 2011b).

A negativ folyamatok ellenére a mezőgazdaság, a csökkenő szerepe ellenére még mindig a nemzetgazdaság egyik fontos ágazata (Burger, 2009), jelentősége ma sem vitatható (bár korántsem nevezhető húzóágazatnak), ezt jelzi a GDP-hez történő hozzájárulása, továbbá az exportban, vagy a foglalkoztatásban betöltött szerepe is (Kapronczai, 2007).

A KSH Cég-Kód-Tár adatai szerint 2010 végén, Magyarországon 544190 társas vállalkozás müködött, ebböl 9668 vállalkozásnak volt fötevékenysége valamilyen mezőgazdasági termék elöállitása (KSH Cég-Kód-Tár, 2010).

\section{CÉLOK}

A publikáció célja a KSH Cég-Kód-Tár 2010 végéig negyedévente frissülő adatbázisából származó alapadatok segítségével bemutatni néhány, a magyarországi mezőgazdasági társas vállalkozásokra jellemző adatot, összefüggést, így:

- egyes cégjellemzöket gyakorisági táblázatokban, valamint

- cégjellemzök - mint ismérvek - közötti sztochasztikus kapcsolatok erősségét.

Mivel az összefüggések elsősorban dinamikusan kezelhető táblák, diagramok segitségével mutathatók be, - a publikáció keretében - a rengeteg adatot tartalmazó adatbázisnak, ill. a kinyerhető összefüggéseknek csak egy-egy részletét van mód felvillantani. 


\section{MÓDSZERTAN}

A Cég-Kód-Tár 2010 végéig rendszeresen közölt adatokat a magyarországi társas vállalkozásokról. A KSH-tól származó adatbázis - többek között - a következő adatokat tartalmazta a vállalkozásokról:

- törzsszám (azonosító),

- név,

- székhely,

- telephely,

- vezetök adatai,

- cégforma,

- fö tevékenység,

- éves árbevétel (kategóriánként), valamint

- foglalkoztatottak létszáma (kategóriánként).

A KSH adatbázisból kiválogattam azokat a társas vállalkozásokat, amelyek

fötevékenysége mezőgazdasági termék-előállitás volt (TEÁOR: 0111-0170). A

fötevékenység az a tevékenység, amely az adott gazdasági egységnél a legnagyobb hozzáadott értéket termeli (KSH, 2007). Az elkészített adatbázis szerkezete látható az 1. ábrán.

7. ábra: Mezőgazdasági társas vállalkozásokat tartalmazó adatbázis szerkezete

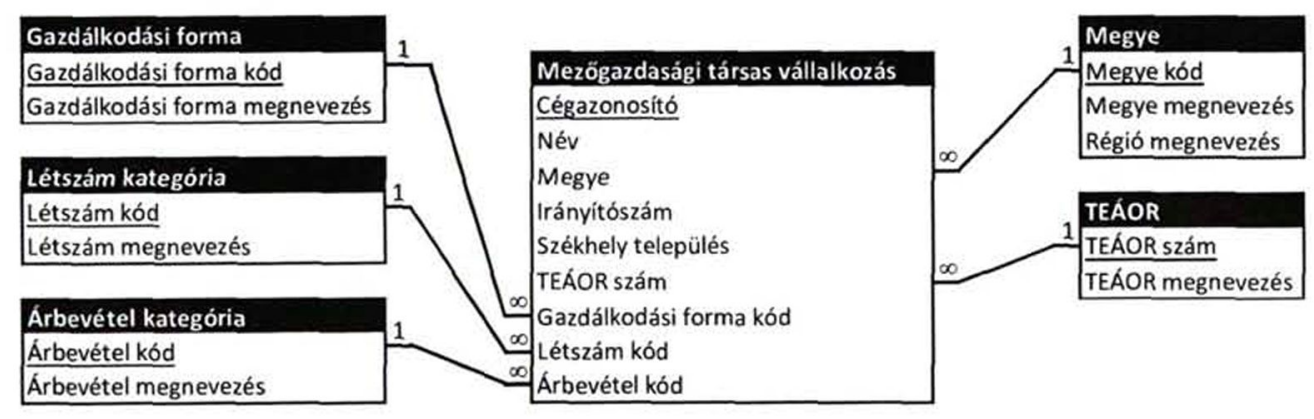

Forrás: saját szerkesztés

Adatbázis-kezelö, valamint táblázatkezelő segítségével gyakorisági táblázatok, diagramok készültek a következő ismérvek felhasználásával: cégforma, fő tevékenység, éves árbevétel, foglalkoztatottak száma, és a székhely (régió, megye, település).

A felsorolt ismérvek közötti tendenciaszerü összefüggéseket is kerestem asszociációs vizsgálatok - Csuprov- és Cramer-féle együtthatók - segítségével.

A $\chi^{2}$ a tényleges és feltételezett gyakoriságok eltérésének mérésére szolgáló mennyiség. A kapcsolat annál szorosabb, minél jobban eltérnek a tényleges és a függetlenség feltételezésével számított gyakoriságok (Korpásné, 1996). Kiszámítása:

$$
\chi^{2}=\sum_{i=1}^{r} \sum_{j=1}^{c} \frac{\left(f_{i j}-f_{i j}^{*}\right)^{2}}{f_{i j}^{*}} \text {, ahol }
$$

- $\mathrm{i}$ és $\mathrm{j}$ : a függőleges és vízszintes irányú ismérv sorszáma $(\mathrm{i}=1, \ldots, \mathrm{r} ; \mathrm{j}=1, \ldots, \mathrm{c})$,

- $\mathrm{r}$ és c: a vízszintes és függőleges irányú ismérvek szerint képzet osztályok száma,

- fij: a tényleges gyakoriságok, 
- $\quad \mathrm{f} * \mathrm{ij}$ : a feltételezett gyakoriságok.

Esetünkben a tényleges gyakoriságok az adatbázis adatai, míg a feltételezett gyakoriságok kiszámításának módja:

$$
f_{i j}^{*}=\frac{f_{i \bullet} \cdot f_{\cdot j}}{N}, \text { ahol }
$$

- $\mathrm{f}_{\mathrm{ij}}$ : a feltételezett gyakoriságok (i=1, $\left.\ldots, \mathrm{r} ; \mathrm{j}=1, \ldots, \mathrm{c}\right)$,

- $\mathrm{f}_{\mathrm{j}}$. és $\mathrm{f}_{\mathrm{j}_{\mathrm{j}}}$ : a sokaság azon egységeinek száma (gyakorisága), amelyek egy adott ismérv szerint egy adott osztályba tartoznak,

- $\quad \mathrm{N}$ : a sokaság egységeinek száma.

A Csuprov-féle együttható 0 és1 közötti értéket vehet fel. 0 akkor, ha a két ismérv egymástól független, míg 1 esetén az egyik ismérv egyértelmủen meghatározza a másik ismérvet, tehát függvényszerủ kapcsolatról beszélhetünk. Kiszámítása:

$$
T=\sqrt{\frac{\chi^{2}}{N \sqrt{s-1} \sqrt{t-1}}} \text {, ahol }
$$

- $\chi^{2}$ : négyzetes kontingencia,

- $\mathrm{N}$ : a sokaság egységeinek száma,

- $\mathrm{s}$ és t: a vízszintes és függőleges irányú ismérvek szerint képzet osztályok száma.

$\mathrm{T}_{\max }=\sqrt[4]{\frac{s-1}{t-1}}$, ha $\mathrm{s} \leq \mathrm{t}$ és reciproka, ha $\mathrm{s}>\mathrm{t}$. (Az s és $\mathrm{t}$ : a vízszintes és függőleges irányú ismérvek szerint képzet osztályok száma.)

A Cramer-féle asszociációs együttható szintén 0 és 1 közötti értékeket vehet fel, kiszámítása a következöképpen történhet:

$$
C=\sqrt{\frac{\chi^{2}}{N(q-1)}} \text {, ahol }
$$

- $\chi^{2}$ : négyzetes kontingencia,

- $\mathrm{N}$ : a sokaság egységeinek száma,

- q: vízszintes irányú ismérvek és a függőleges irányú ismérvek szerint képzet osztályok száma közül a kisebb érték.

Az összefüggés-vizsgálatokat az ismérvek között, minden lehetséges, értelmes kombinációban elvégeztem:

- Cégforma - fötevékenység,

- Cégforma - éves árbevétel,

- Cégforma - foglalkoztatottak száma,

- Cégforma - régió,

- Cégforma - megye,

- Cégforma - székhely,

- Fötevékenység - éves árbevétel,

- Főtevékenység - foglalkoztatottak száma,

- Főtevékenység - régió, 
- Fötevékenység - megye,

- Fötevékenység - székhely,

- Éves árbevétel - foglalkoztatottak száma,

- Éves árbevétel - régió,

- Éves árbevétel - megye,

- Éves árbevétel - székhely,

- Foglalkoztatottak száma - régió,

- Foglalkoztatottak száma - megye,

- Foglalkoztatottak száma - székhely.

\section{EREDMÉNYEK}

A 9668 mezőgazdasági fötevékenységet folytató társas vállalkozásból azokat vizsgáltam, ahol az éves árbevétel és a foglalkoztatottak száma nem volt ismeretlen; ez 8831 céget jelentett. A legtöbb vizsgált tevékenységet végző társas vállalkozás székhelye a DélAlföldön (19\%) található, a második helyen Eszak-Alföld áll (18\%), míg KözépMagyarországé a harmadik hely $(17 \%)$; e három régióban működik a vállalkozások kétharmada $(67 \%)$.

Ha a fóvárost és a megyéket vizsgáljuk, kiderül, hogy a vállalkozások száma szerinti sorrendben Pest megye (az összes mezőgazdasági társas vállalkozás 10\%-a), Bács-Kiskun (9\%), Hajdú-Bihar (7\%) és Budapest (7\%) áll az élen; a vállalkozások harmadának székhelye található itt. Békés megye a 6 . helyen áll (6\%), míg Csongrád megye a 13. helyen szerepel a megyék sorrendjében.

A vizsgált vállalkozások 2000 településen rendelkeznek székhellyel (a föváros 23 kerületét külön településeknek számítva). A legtöbb cégnek Budapesten található a székhelye (635 db). Több mint félszáz mezögazdasági társas vállalkozás müködik a következö településeken:

- Debrecen (142 db),

- Nyíregyháza (104 db),

- Kecskemét (91 db),

- Pécs (72 db),

- Szeged (61 db),

- Szentes (61 db),

- Szarvas (60 db),

- Györ (56 db).

Tizenegyféle társas vállalkozási formában folytatják a cégek a tevékenységüket, ebböl hattizedük korlátolt felelősségü társaságként és negyed részük betéti társaságként tevékenykedik, illetve jelentős még a mezőgazdasági szövetkezetek (8\%), valamint a részvénytáraságok aránya (3\%).

A vállalkozások közel kilenctizede mikro- ill. kisvállalkozásnak tekinthető (európai mércével mérve): A cégek több mint felének (55\%) éves árbevétele nem éri el a 20 millió forintot, 20-50 millió forint éves bevétellel rendelkezik a cégek alig több mint tizede (13\%), továbbá 51-300 millió forint éves árbevételt a társas vállalkozások ötöde (21\%) ért el. A vizsgált vállalkozások több mint nyolctizedében (83\%) a foglalkoztatottak szám a nem éri el a 10 föt, száznál kevesebb föt foglalkoztat a mezőgazdasági társas vállalkozások $99 \%-\mathrm{a}$. (Az éves árbevétellel és a foglalkoztatottak számával kapcsolatos számításokat némiképp árnyalja, hogy mindkét esetben körülbelül $10 \%$ azoknak a hazai cégeknek az aránya, ahol ez az adat nem ismert.) 
A Gazdasági Tevékenységek Egységes Ágazati Osztályozási Rendszerében szereplö huszonnyolcféle mezögazdasági tevékenységböl a társas vállalkozások $80 \%$-a összesen mindössze nyolcféle tevékenységet végez fötevékenységként. Ezek a fötevékenységek - a vállalkozások relativ gyakorisága szerinti csökkenő sorrendben - a következök:

- gabonaféle (kivéve: rizs), hüvelyes növény, olajos mag termesztése (a vállalkozások $34 \%-a)$,

- növénytermesztési szolgáltatás (18\%),

- baromfitenyésztés (7\%),

- zöldségféle, dinnye, gyökér-, gumósnövény termesztése (5\%),

- sertéstenyésztés (4\%),

- almatermésủ, csonthéjas termesztése gyártása (4\%),

- tejhasznú szarvasmarha tenyésztése (3\%),

- állattenyésztési szolgáltatás (3\%).

A 2-4. ábra diagramjai a vizsgált vállalkozások néhány fontosabb jellemzöit mutatják két ismérv szerint csoportositva, így: az éves árbevétel és a foglalkoztatottak száma szerinti, az éves árbevétel és a cégforma szerinti, valamint a régiók és éves árbevétel szerinti megoszlást.

8. ábra: Mezőgazdasági társas vállalkozások foglalkoztatottak száma szerinti aránya Magyarországon éves árbevétel kategóriánként (2010, 4. negyedév)

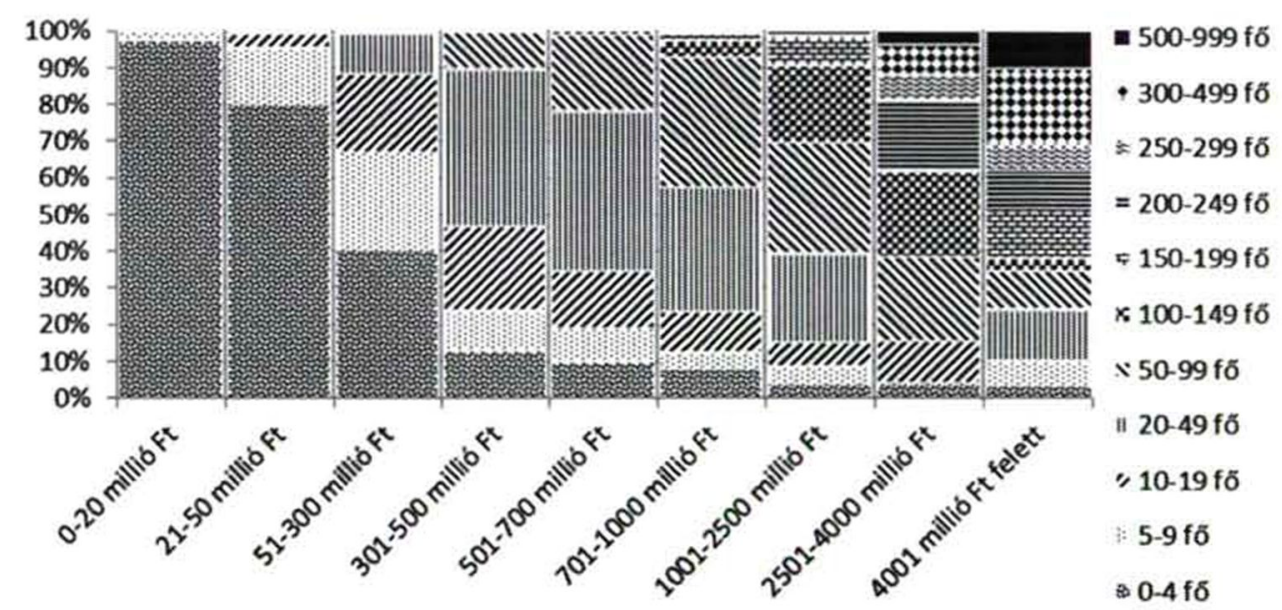

Forrás: KSH adatok alapján saját szerkesztés 
9. ábra: Mezőgazdasági társas vállalkozások cégforma szerinti aránya Magyarországon éves árbevétel kategóriánként $(2010,4$. negyedév)

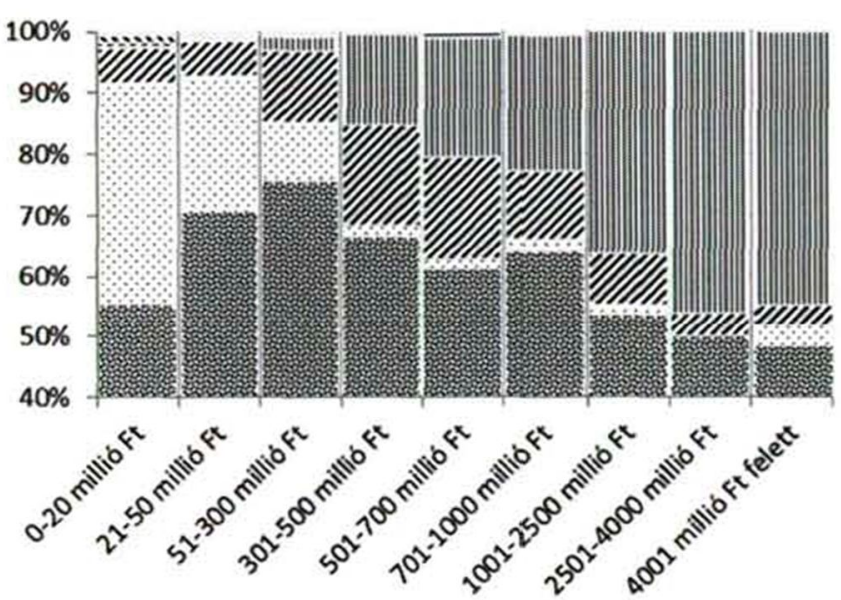

- kőzōs vállalat

: külfơldi székhelyũ vâllalkozás fióktelepe

? egyénicég

^erdő́birtokossági társulat

a egyéb szớvetkezet

: máshova nem sorolt, jogi személyiség

nélikuli vállalkozás

^ közkereseti társaság

" részvénytársaság

: mezógazdasági szővetkezet

betéti társaság

ะ kơlátolt felelổsségũ társaság

Forrás: KSH adatok alapján saját szerkesztés

A Csuprov- és Cramer-féle asszociációs együtthatók értékeit az 1. táblázat tartalmazza a kapcsolat erösségének megfelelöen rendezett sorrendben. A vizsgálatok alapján megállapítható, hogy a vizsgált jellemzők közül önmagában egyik sem alkalmas arra, hogy abból egy másik jellemzőre nagy biztonsággal következtetni lehessen. A számítások közepes erősségü kapcsolatot mutattak ki a vállalkozások székhelye és fötevékenysége, valamint cégformája, továbbá közepesnél kissé gyengébb kapcsolat volt kimutatható a székhely, a foglalkoztatottak száma, illetve az árbevétel között. Minden más esetben csak gyenge kapcsolat volt felfedezhetö.

10. ábra: Mezőgazdasági társas vállalkozások éves árbevétel kategória szerinti aránya Magyarországon régiónként (2010,4. negyedév)

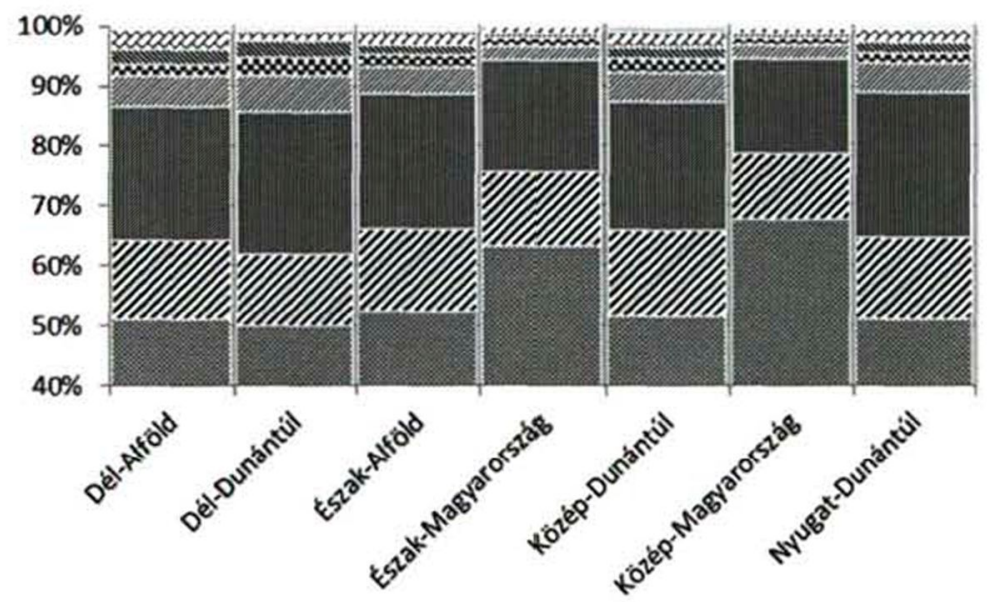

n 4001 millió $\mathrm{Ft}$ felett

$=2501-4000$ millió $\mathrm{Ft}$

s 1001-2500 millió Ft

* 701-1000 millió Ft

\501-700 millió $\mathrm{Ft}$

301-500 millió $\mathrm{Ft}$

= 51-300 millió $\mathrm{Ft}$

\%. 21-50 millió $\mathrm{Ft}$

0-20 millió $\mathrm{Ft}$

Forrás: KSH adatok alapján saját szerkesztés 
1. táblázat: A kapcsolat szorossága a vizsgált ismérvek között

\begin{tabular}{|c|c|c|c|c|c|c|c|c|c|}
\hline Ismérv 1 & Ismérv 2 & $x^{2}$ & s & $t$ & $\mathbf{N}$ & $T \max$ & Csuprov & Cramer & Kapcsolat erōssége \\
\hline Fō tevékenység & Székhely & 65189,3517 & 2000 & 28 & 8831 & 0,3409 & 0,1783 & 0,5229 & kōzepes \\
\hline Cégforma & Székhely & 22449,2814 & 2000 & 11 & 8831 & 0,2659 & 0,1341 & 0,5042 & közepes \\
\hline Éves árbevétel & Székhely & 15233,3009 & 2000 & 9 & 8831 & 0,2515 & 0,1168 & 0,4644 & kōzepesen gyenge \\
\hline Foglalkoztatottak száma & Székhely & 16086,8377 & 2000 & 11 & 8831 & 0,2659 & 0,1135 & 0,4268 & közepesen gyenge \\
\hline Éves árbevétel & Foglalkoztatottak száma & 12825,5118 & 9 & 11 & 8831 & 0,9457 & 0,4030 & 0,4261 & közepesen gyenge \\
\hline Cégforma & Fö tevêkenység & 3997,0170 & 28 & 11 & 8831 & 0,7801 & 0,1660 & 0,2127 & gyenge \\
\hline Cégforma & Éves árbevétel & 2592,2572 & 9 & 11 & 8831 & 0,9457 & 0,1812 & 0,1916 & gyenge \\
\hline Cégforma & Foglalkoztatottak száma & 3007,6818 & 11 & 11 & 8831 & 1,0000 & 0,1845 & 0,1845 & gyenge \\
\hline Fö tevékenység & Éves árbevétel & 1550,4812 & 28 & 9 & 8831 & 0,7378 & 0,1093 & 0,1481 & gyenge \\
\hline Fó tevékenység & Régió & 1110,2761 & 28 & 7 & 8831 & 0,6866 & 0,0994 & 0,1448 & gyenge \\
\hline Fō tevékenység & Foglalkoztatottak száma & 1358,3313 & 28 & 11 & 8831 & 0,7801 & 0,0968 & 0,1240 & gyenge \\
\hline Fō tevékenység & Megye & 2366,9399 & 28 & 20 & 8831 & 0,9159 & 0,1088 & 0,1188 & gyenge \\
\hline \begin{tabular}{|l|} 
Éves árbevétel \\
\end{tabular} & Megye & 450,8122 & 20 & 9 & 8831 & 0,8055 & 0,0643 & 0,0799 & gyenge \\
\hline Cégforma & Megye & 531,9180 & 20 & 11 & 8831 & 0,8517 & 0,0661 & 0,0776 & gyenge \\
\hline Cégforma & Régió & 260,1992 & 7 & 11 & 8831 & 0,8801 & 0,0617 & 0,0701 & gyenge \\
\hline Éves árbevétel & Régió & 227,9572 & 9 & 7 & 8831 & 0,9306 & 0,0610 & 0,0656 & grenge \\
\hline Foglalkoztatottak száma & Megye & 332,1027 & 20 & 11 & 8831 & 0,8517 & 0,0522 & 0,0613 & gyenge \\
\hline Foglalkoztatottak száma & Régió & 134,6668 & 11 & 7 & 8831 & 0,8801 & 0,0444 & 0,0504 & gyenge \\
\hline
\end{tabular}

Forrás: KSH adatok alapján saját szerkesztés

\section{IRODALOMJEGYZÉK}

Burger, Anna (2009): The Situation of Hungarian Agriculture. Research in Agricultural \& Applied Econimics. AgEcon Search, Miscellaneous Papers. pp. 1-15. http://purl.umn.edu/90651 (letöltés: 2012.12.12.)

Kapronczai István (2007): Információs rendszerek a közös agrárpolitika szolgálatában. Szaktudás Kiadó Ház. Budapest.

Korpás Attiláné (szerk.) (1996): Ảltalános statisztika I. Nemzeti Tankönyvkiadó. Budapest.

Központi Statisztikai Hivatal (2007): Útmutató a gazdasági egységek statisztikai fötevékenységének meghatározásához. http://www.ksh.hu/docs/files/726821.pdf (letöltés: 2010.01.26.)

Központi Statisztikai Hivatal (2011): A fontosabb szántóföldi növények betakarított területe, összes termése és termésátlaga (1990-) http://www.ksh.hu/docs/hun/xstadat/ xstadat_eves/i_omn007.html (letöltés: 2012.10.10.)

Központi Statisztikai Hivatal (2011): A fontosabb állati termékek termelése (1990-) http://www.ksh.hu/docs/hun/xstadat/xstadat_eves/i_oma002.html (letöltés: 2012.10.10.)

KSH Cég-Kód-Tár 2010/4. 